\title{
PENGARUH JUMLAH PENDUDUK MUSLIM, PEMBIAYAAN, DAN BAGI HASIL TERHADAP JUMLAH NOMINAL TABUNGAN NASABAH PADA BANK SYARIAH DI INDONESIA
}

\author{
Sudarmin Amdar, Ventje Ilat, Agus Tony Poputra \\ (mamink.amdar@gmail.com)
}

\begin{abstract}
Banking world to be part of a country's economic success. More and more financial institutions that exist in a country, the better the economic turnaround that is therein. The reason the economy was good for people who have more funds can save their money to the bank. While people who need funds to start a business or to add funds to enlarge the business can borrow directly in the bank nearest to the given requirements. The purpose of this study was to determine the Impact of the Muslim population, financing, and for the results of the nominal amount of savings in Islamic Banking in Indonesia. Data collection method used is through surveys and data analysis. Techniques to test the hypothesis by using multiple linear regression analysis processed SPSS version 21. Location research done that is through internet websites and annual financial statements on Islamic Banking in Indonesia, which consists of: PT Bank BRI Syariah, Bank Syariah Bukopin, Bank Syariah Mandiri, Bank Panin Syariah, PT Bank Muamalat Indonesia during the year 2009-2013. Muslim population (X1) not significant effect on the nominal amount of savings $(Y)$. Financing (X2) significantly affects nominal amount of savings $(Y)$. For results $(X 3)$ no significant effect on the nominal amount of savings $(Y)$.

Keywords: impact of the muslim population, financing, and profit sharing the number nominal customer savings
\end{abstract}

\section{PENDAHULUAN}

Lembaga keuangan perbankan menjadi salah satu lembaga yang membantu masyarakat dalam melakukan transaksi simpanan uang dan pinjaman uang. Perusahaan yang bergerak dibidang keuangan memegang peranan sangat penting dalam memenuhi akan kebutuhan dana. Hal ini disebabkan perusahaan keuangan memang bidang utama usahanya adalah menyediakan fasilitas pembiayaan dana bagi perusahaan lainnya. Dana merupakan masalah pokok yang selalu ada dan selalu muncul dalam setiap usaha. Lembaga keuangan perbankan secara umum yang diterapkan di Indonesia ada dua yaitu Bank Konvensional dan Bank Syariah. Pada dasarnya lembaga keuangan ini menjalankan kegiatan perbankan sama yang membedakan adalah sistem pengelolaannya. Bank Konvensional menerapkan sistem bunga sedangkan Bank Syariah menerapkan sistem bagi hasil. Lincolin Arsyad (1999:1) menyatakan bahwa pembahasan tentang masalah pembangunan ekonomi bukanlah suatu perkembangan baru dalam ilmu ekonomi, karena studi tentang pembangunan ekonomi tersebut telah menarik perhatian para pakar ekonomi sejak zaman kaum Merkantilis, kaum klasik, sampai Marx dan Keynes. Ekonomi suatu daerah dipengaruhi oleh jumlah penduduk yang tinggal di daerah itu sendiri, kebudayaan, agama, sosial, dan adat istiadat. Perekonomian akan berjalan dengan baik dan berkembang dengan lancar apabila lembaga keuangan yang ada di daerah berjalan dengan baik. Bank syariah salah satunya lembaga keuangan yang menawarkan berbagai macam produk tabungan dan juga pembiayaan yang mampu membantu kelancaran perekonomian penduduk sehingga berdampak pada kesejahteraan yang secara tidak langsung memberikan kontribusi yang positif. 
Umat Islam di Indonesia adalah mayoritas muslim. Indonesia adalah negara dengan jumlah penduduk muslim terbesar di dunia. Angka statistik pertumbuhan umat Islam Indonesia pada sensus penduduk tahun 1990 jumlah umat Islam mencapai 87,6 persen, dan angka ini kemudian meningkat menjadi 88,2 persen pada sensus penduduk tahun 2000 dan hingga sekarang mencapai 91,03 \%. Antonio (2001:95) menyatakan bahwa praktik Bank Syariah memiliki beberapa keunggulan dibandingkan dengan Bank Konvensional, yaitu pertama adalah mendorong adanya kebersamaan dalam menghadapi resiko usaha dan membagi keuntungan secara adil.Simpanan mudharabahadalah simpanan berdasarkan kaidah syariah mudharabah almuthlaqah, dimana mudharib memberikan kepercayaan kepada Bank untuk memanfaatkan dana yang dapat digunakan dalam bentuk pembiayaan secara produktif, dapat memberikan manfaat pada anggota yang lain secara halal dan profesional. Pembiayaan menjadi salah satu bentuk solusi bagi para nasabah yang membutuhkan dana dalam jumlah besar, dengan syarat dan jaminan tertentu proses pembiayaan dapat disepakati oleh kedua belah pihak. Pembiayaan pada bank syariah mengalami perkembangan yang sangat signifikan sehingga menimbulkan berbagai macam permasalahan serta mekanisme proses pembiayaan.

Jumlah nominal tabungan nasabah merupakan seluruh dana yang dimiliki dan disimpan di bank oleh nasabah. Nasabah merupakan item paling penting dan sangat menentukan maju mundurnya suatu bank. Berdasarkan UU Republik Indonesia Nomor 21 tahun 2008 tentang Perbankan Syariah nasabah adalah pihak yang menggunakan jasa Bank Syariah atau Unit usaha Syariah. Hasil analisis dan pengujian mengenai pengaruh jumlah penduduk muslim, pembiayaan dan bagi hasil terhadap jumlah nominal tabungan nasabah pada PT Bank BRI Syariah, Bank Syariah Bukopin, Bank Syariah Mandiri, Panin Bank Syariah, PT Bank Muamalat Indonesia. Dengan alat analisa paradigma jalur maka diperoleh hasil perhitungan yang menjawab dugaan dalam penelitian. Jumlah penduduk muslim tidak berpengaruh signifikan terhadap jumlah nominal tabungan nasabah disebabkan oleh adanya faktor-faktor yang mendorong penduduk muslim menabung di bank syariah antara lain adalah faktor perilaku, ekonomi, keluarga, keuntungan, lokasi bank yang bersangkutan. Hasil penelitian ini didukung oleh peneliti Metawa dan Almossawi (1998), Khairunnisa (2000), Halim Alamsyah (2015), Veni Rahmi Yusni (2011) serta teori Lincolin Arsyad (1999).

Pembiayaan berpengaruh signifikan terhadap jumlah nominal tabungan nasabah disebabkan oleh kebutuhan masyarakat akan peningkatan kesejahteraan untuk pembiayaan yang sifatnya produktif dan pembiayaan konsumtif sehingga masyarakat merasa terbantu dengan adanya produk penyaluran dana (pembiayaan), produk penghimpunan dana (menabung) dan produk yang berkaitan dengan jasa lain. Hasil penelitian ini didukung oleh peneliti Sutiani (2012) serta teori Antonio (2001) dan Kasmir (2013). Bagi hasil tidak berpengaruh signifikan terhadap jumlah nominal tabungan nasabah disebabkan oleh adanya inovasi baru Bank Konvensional yang memberikan kredit dengan sistem pembebanan bunga dengan flat rate, dan juga sliding rate. Hasil penelitian ini didukung oleh peneliti Ghafur (2003), Fadhila (2004) serta teori Ismail (2010), Dewan Syariah Nasional Majelis Ulama Indonesia dan Kasmir (2013).

\section{TINJAUAN PUSTAKA}

\section{Bank Syariah}

Pengertian Bank Syariah menurut UU. Nomor 21 Tahun 2008 pasal 1 ayat 1, menyatakan bahwa perbankan syariah adalah segala sesuatu yang menyangkut tentang bank syariah dan unit usaha syariah, mencakup kelembagaan, kegiatan usaha serta cara dan proses pelaksanaan kegiatan usahanya. Sedangkan pengertian Bank Syariah dalam pasal 1 ayat 7 menyatakan bahwa 
Bank Syariah adalah bank yang menjalankan kegiatan usahanya berdasarkan prinsip syariah dan menurut jenisnya sendiri atas bank umum syariah dan bank pembiayaan kredit syariah. Di dalam pasal 1 ayat 3 dan 4 UU. Nomor 10 Tahun 1998 bahwa Bank Syariah adalah bank umum maupun Bank Perkreditan Rakyat di dalam melaksanakan kegiatan usaha berdasarkan prinsip syariah atau sesuai aturan dalam hukum Islam yang berdasarkan pada Alquran dan Al-Hadits, ijma para sahabat dan Qias Ulama.

Jenis simpanan yang ditawarkan oleh bank beraneka ragam, diantaranya deposito berjangka atau deposito berjangka untuk pembangunan yang mulai diperkenalkan oleh pemerintah secara serentak pada tanggal 15 september 1968. Latar belakang dikeluarkannya Instruksi Presiden Nomor 28 Tahun 1968 adalah untuk lebih memanfaatkan perkreditan serta dana-dana dari kalangan masyarakat untuk mensukseskan stabilitas dan pembangunan ekonomi. Pengertian deposito menurut pasal 1 angka 7 undang-undang nomor 10 Tahun 1998 tentang perbankan adalah simpanan yang penarikannya hanya dapat dilakukan pada waktu tertentu berdasarkan perjanjian nasabah penyimpan dengan bank, artinya jika nasabah atau deposan menyimpan uangnya untuk jangka waktu tiga bulan, maka uang tersebut baru dapat dicairkan setelah jangka waktu tersebut berakhir dan sering disebut tanggal jatuh tempo (Kasmir, 2013:75).

\section{Perkembangan Akuntansi Syariah dan jumlah penduduk muslim di Indonesia}

Sri Nurhayati (2009:50) menyatakan pada awalnya akuntansi merupakan bagian dari ilmu pasti yaitu bagian dari ilmu pengetahuan yang berhubungan dengan masalah hukum alam dan perhitungan yang bersifat memiliki kebenaran absolute. Sebagai bagian ilmu pasti yang perkembangannya bersifat akumulatif, maka setiap penemuan metode baru dalam akuntansi akan menambah dan memperkaya ilmu akuntansi tersebut. Bahkan pemikir akuntansi pada awal perkembangannya adalah seorang ahli matematika seperti Luca Paciolli dan Musa AlKhawarizmy. Lincolin Arsyad (1999:1), menyatakan pembahasan tentang masalah pembangunan ekonomi bukanlah suatu perkembangan baru dalam ilmu ekonomi, karena studi tentang pembangunan ekonomi tersebut telah menarik perhatian para pakar ekonomi sejak zaman kaum Merkantilis, kaum klasik, sampai Marx dan Keynes.

\section{Faktor-faktor yang mempengaruhi perkembangan perbankan syariah di Indonesia}

1. Efisiensi.

2. Pendidikan dan pengetahuan masyarakat tentang perbankan syariah dan bunga.

3. Regulasi.

4. Fatwa bahwa bunga bank adalah haram dan riba.

5. Terbukti unggul menghadapi kritis.

6. Integrasi Lembaga Keuangan Syariah (LKS).

7. Daya saing perbankan syariah di Indonesia.

8. Dari laporan Karim Consulting terhadap kajian atas 130 bank syariah diseluruh dunia dalam rangka International Islamic Banking Award (IIBA) 2005, memberikan hasil yang menarik tingkat profitabilitas bank syariah di Indonesia merupakan yang terbaik didunia diukur dari rasio laba terhadap asset (ROA), baik untuk kategori bank yang full fledge maupun untuk kategori unit usaha syariah.

9. Meningkatnya kesadaran keislaman masyarakat.

10. Masyarakat muslim terbesar didunia ada di Indonesia. Ini merupakan pasar potensial yang sangat menggiurkan para pelaku bank syariah, apalagi diiringi dengan semakin baiknya 
kesejahteraan masyarakat, seharusnya di Indonesialah pasar perbankan syariah terbesar didunia.

\section{Pembiayaan}

Untuk kelancaran menjalankan usaha setiap perusahaan membutuhkan dana untuk peningkatan pengelolaannya. Bank memberikan pinjaman dalam bentuk pembiayaan kepada nasabah sesuai dengan ketentuan yang berlaku diperbankan. Antonio (2001:160), mengemukakan bahwa pembiayaan merupakan salah satu tugas pokok bank, yaitu pemberian fasilitas penyediaan dana untuk memenuhi kebutuhan pihak-pihak yang merupakan defisit unit menurut sifat penggunaannya, pembiayaannya dapat dibagi menjadi dua hal berikut.

1. Pembiayaan produktif, yaitu pembiayaan yang ditujukan untuk memenuhi kebutuhan produksi dalam arti luas, yaitu untuk peningkatan usaha, baik usaha produksi, perdagangan, maupun investasi.

2. Pembiayaan konsumtif, yaitu pembiayaan yang digunakan untuk memenuhi kebutuhan konsumsi, yang akan habis digunakan untuk memenuhi kebutuhan.

Menurut keperluannya, pembiayaan produktif dibagi menjadi dua hal sebagaimana berikut :

1. Pembiayaan modal kerja, yaitu pembiayaan untuk memenuhi kebutuhan: (1) Peningkatan produksi, baik secara kuantitatif, yaitu jumlah hasil produksi, maupun secara kualitatif, yaitu peningkatan kualitas atau mutu hasil produksi:dan (2) untuk keperluan perdagangan atau peningkatan utility of place dari suatu barang.

2. Pembiayaan investasi,yaitu untuk memenuhi kebutuhan barang-barang modal (capital goods) serta fasilitas-fasilitas yang erat kaitannya dengan itu secara umum.

Secara nasional, Perbankan Syariah di Indonesia saat ini menggunakan akad Murabahah sebagai salah satu produk utama pembiayaannya. Hal ini dikarenakan oleh sistem dan teknik penghitungannya yang lebih mudah dicerna baik oleh nasabah maupun oleh pihak bank, sehingga aspek kejelasan lebih mengedepan (Antonio, 2001:161). Melalui Fatwa Dewan Syariah Nasional No. 04/DSN-MUI/IV/2000 tentang murabahah, Dewan Syariah Nasional telah memberikan izin operasional sesuai syariah terhadap produk pembiayaan murabahah. Dengan spirit Surat Al-Baqarah ayat 275 yang menyatakan bahwa Allah menghalalkan jual beli dan mengharamkan riba, serta beberapa ayat lainnya yang terdapat dalam Al-Quran, Murabahah ini di daulat menjadi kunci dari seluruh kebutuhan nasabah akan produk pembiayaan syariah. Murabahah merupakan pembiayaan yang memposisikan nasabah sebagai pembeli dan bank sebagai penjual, dan operasional murabahah ini murni menggunakan rukun dan syarat jual beli, dimana terdapat beberapa hal yang harus ada dalam transaksi jual beli tersebut. Harus ada penjual, pembeli, objek yang diperjual belikan, ada ijab dan qabul serta ada akad yang menyertai perjanjian jual beli ini. Berdasarkan jenis akadnya, pembiayaan syariah dibedakan menjadi :

1. Pembiayaan Murabahah.

2. Pembiayaan Salam

3. Pembiayaan Istishna'

4. Pembiayaan Musyarakah

5. Pembiayaan Mudharabah

6. Pembiayaan Ijarah

7. Pembiayaan Ijarah Muntahiyah Bittamlik 


\section{Bagi Hasil}

Bagi Hasil Menurut Terminologi asing (Inggris) dikenal dengan "profit sharing". Profit sharing dalam kamus ekonomi diartikan sebagai laba. Secara definitif profit sharing diartikan: "distribusi beberapa bagian dari laba pada para pegawai dari suatu perusahaan". Menurut Standar Akuntansi Keuangan, (2009:105.1) Bagi hasil (mudharabah) adalah akad kerja sama usaha antara dua pihak dimana pihak pertama (pemilik dana) menyediakan seluruh dana, sedangkan pihak kedua (pengelola dana) bertindak selaku pengelola, dan keuntungan dibagi diantara mereka sesuai kesepakatan sedangkan kerugian financial hanya ditanggung oleh pemilik dana. Sebagaimana diketahui, bank yang beroperasi berdasarkan prinsip-prinsip Islam menawarkan sistem bagi hasil kepada nasabahnya.

Perhitungan bagi hasil di bank syariah ada dua jenis; pertama Profit/Loss Sharing. Dalam sistem ini, besar-kecil pendapatan bagi hasil yang diterima nasabah tergantung keuntungan bank. Kedua Revenue Sharing dalam sistem ini, penentuan bagi hasil akan tergantung pada pendapatan kotor bank. Bank-bank syariah di Indonesia umumnya menerapkan sistem Revenue Sharing. Pola ini dapat memperkecil kerugian bagi nasabah, hanya saja jika bagi hasil didasarkan pada profit sharing, maka presentase bagi hasil untuk nasabah akan jauh lebih tinggi.

\section{Teori tentang Menabung}

Kasmir (2013:69-70), mengemukakan seperti halnya simpanan giro, simpanan tabungan juga mempunyai syarat-syarat tertentu bagi pemegangnya dan persyaratan masing-masing bank berbeda satu sama lainnya. Ada beberapa alat penarikan tabungan, hal ini tergantung bank masing-masing, mau menggunakan sarana yang diinginkan. Alat ini dapat digunakan sendirisendiri atau secara bersamaan. Alat-alat yang dimaksud adalah : Buku tabungan, slip penarikan, kwitansi, kartu yang terbuat dari plastik. Pengertian tabungan menurut UU perbankan Nomor 10 tahun 1998 adalah simpanan yang penarikannya hanya dapat dilakukan menurut syarat-syarat tertentu yang disepakati, tetapi tidak dapat ditarik dengan cek, bilyet giro dan atau alat lainnya yang dipersamakan dengan itu (Kasmir, 2010:57). Semakin tinggi tingkat bunga (tingkat bunga kredit), maka keinginan untuk melakukan investasi juga semakin kecil. Alasannya, seorang pengusaha akan menambah pengeluaran investasinya apabila keuntungan yang diharapkan dari investasi tersebut lebih besar dari tingkat bunga yang harus dibayarkan untuk dana investasi tersebut sebagai ongkos untuk penggunaan dana (cost of capital).

\section{Menabung Yang Islami}

Ismail, (2010:29) meyatakan bahwa pemikiran ekonomi Islam sebenarnya selalu terinspirasi oleh maksud-maksud moral. Hal ini diikuti oleh perintah-perintahnya yang meletakkan tujuan sosial dan norma-norma individu pada pelaku yang relevan terhadap tata kehidupan ekonomi manusia. Menabung adalah tindakan yang dianjurkan oleh Islam karena dengan menabung berarti seorang muslim mempersiapkan diri untuk pelaksanaan perencanaan masa depan sekaligus untuk menghadapi hal-hal yang tidak diinginkan. Menabung adalah salah satu langkah dari persiapan tersebut.(Antonio, 2000:205-206).

\section{Penelitian Terdahulu}

Beberapa peneliti terdahulu yang pernah melakukan penelitian tentang pembiayaan, bagi hasil, dan suku bunga yang berkaitan dengan penelitian ini adalah sebagai berikut :

1. Ghafur (2003), melihat hubungan antara bagi hasil, suku bunga serta pendapatan terhadap simpanan mudharabah di Bank Muamalat Indonesia. Kesimpulan dari penelitian tersebut 
adalah bahwa bagi hasil dan suku bunga tidak berpengaruh signifikan terhadap simpanan di Bank Muamalat Indonesia.

2. Fadhila (2004), meneliti tentang tingkat bagi hasil dan suku bunga terhadap simpanan mudharabah pada Bank Syariah Mandiri, disimpulkan bahwa variabel tingkat bagi hasil berpengaruh tidak signifikan terhadap simpanan mudharabah di Bank Syariah Mandiri, sedangkan variabel suku bunga berpengaruh negatif dan signifikan terhadap simpanan mudharabah di Bank Syariah Mandiri.

3. Khairunnisa (2000), meneliti faktor-faktor apa saja yang mendorong nasabah dalam memilih bank syariah. Hasil dari penelitian tersebut adalah bahwa faktor ekonomi adalah faktor pendorong nasabah dalam memilih bank syariah.

4. Haroon dan Ahmad (2000), meneliti apakah tingkat bunga bank konvensional mempunyai hubungan langsung dengan simpanan dibank syariah. Hasil penelitian ini adalah bahwa tingkat keuntungan di bank syariah dengan total jumlah simpanan adalah positif, dimana dengan terjadinya peningkatan tingkat keuntungan di bank syariah akan mendorong peningkatan total simpanannya.

5. Metawa dan Almossawi (1998), melakukan penelitian yang bertujuan untuk mengidentifikasi perilaku nasabah bank syariah dalam memilih bank syariah. Kesimpulan dari penelitian ini adalah bahwa keputusan nasabah dalam memilih bank syariah adalah karena didorong oleh faktor keuntungan, dorongan keluarga dan teman serta lokasi bank yang bersangkutan.

6. Widiastama (2006), mencoba menguji pengaruh variabel total bagi hasil, tingkat suku bunga deposito, dan fatwa Majelis Ulama Indonesia yang terkait dengan haramnya bunga bank terhadap simpanan mudharabah pada Bank Muamalat Indonesia.

7. Sutiani (2012) menguji hubungan imbalan bagi hasil, pembiayaan dan suku bunga terhadap jumlah nominal tabungan nasabah pada Bank Syariah di Indonesia. Hasil penelitian imbalan bagi hasil terdapat hubungan positif terhadap jumlah nominal tabungan nasabah, pembiayaan terdapat hubungan positif terhadap jumlah nominal tabungan nasabah, dan suku bunga terdapat hubungan negatif terhadap jumlah nominal tabungan nasabah.

\section{KERANGKA KONSEPTUAL}

Berdasarkan beberapa konsep penelitian terdahulu dan landasan teori, maka peneliti menduga bahwa terdapat pengaruh jumlah penduduk muslim, pembiayaan, bagi hasil terhadap jumlah nominal tabungan nasabah pada Bank Syariah Di Indonesia periode tahun 2009 - 2013. Jumlah penduduk muslim mempunyai potensi untuk menambah nasabah Bank Syariah. Hal ini disebabkan oleh adanya faktor perilaku nasabah, keputusan nasabah di dalam menentukan pilihan bank, ekonomi, dan kepercayaan nasabah terhadap bank yang mengakibatkan adanya pengaruh pada jumlah nominal tabungan nasabah. Sehingga dengan adanya faktor-faktor tersebut maka akan mempengaruhi aktivitas bank dalam menerima simpanan nasabah sebagai tabungan yang menguntungkan kedua belah pihak.

Pembiayaan mempunyai pengaruh sangat besar dalam perbankan, karena sumber dana yang disalurkan kepada nasabah akan memberikan umpan balik berupa pengembalian dalam bentuk bagi hasil atau bunga untuk bank konvensional. Kompensasi atas pembiayaan yang dilakukan memberikan respon positif sebagai investasi yang menguntungkan bagi kedua belah pihak. Sehingga dengan adanya transaksi pembiayaan ini nasabah wajib membuka rekening di bank dan hal tersebut akan mempengaruhi jumlah nominal tabungan nasabah. Bagi hasil menjadi bagian terpenting bagi nasabah hal ini dikarenakan bagi hasil merupakan imbalan yang diberikan kepada nasabah atas simpanan atau pinjaman yang dilakukan. Kompensasi atas bagi hasil yang 
diterima merupakan hasil dari pengelolaan dana yang disimpan nasabah atau yang dipinjam nasabah, mempunyai dampak pada jumlah nominal tabungan nasabah. Ringkasan dapat dilihat pada Gambar 1.

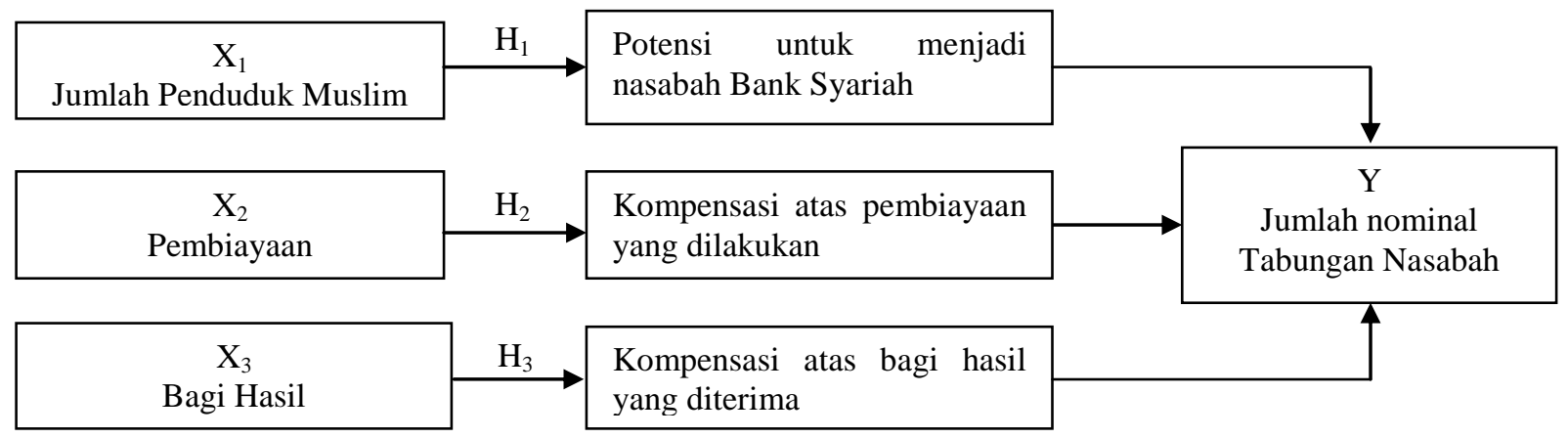

\section{Gambar 1. Kerangka Konseptual}

Berdasarkan permasalahan dalam penelitian maka hipotesis dapat dirumuskan sebagai berikut : $\mathrm{H}_{1}$ Diduga jumlah penduduk muslim berpengaruh terhadap jumlah nominal tabungan nasabah. $\mathrm{H}_{2}$ Diduga pembiayaan berpengaruh terhadap jumlah nominal tabungan nasabah. $\mathrm{H}_{3}$ Diduga bagi hasil berpengaruh terhadap jumlah nominal tabungan nasabah.

Untuk penelitian ini penulis melakukan pengujian model analisis regresi linier berganda. Analisis regresi linier berganda, menurut Sugiyono, (2011:250) analisis regresi linier berganda digunakan oleh peneliti bila peneliti bermaksud meramalkan bagaimana keadaan (naik/turunnya) variabel dependen bila dua atau lebih variabel independen. Uji regresi liner dengan dua atau lebih variabel independen digunakan untuk meramalkan suatu variabel dependen Y berdasarkan dua atau lebih variabel independen dalam suatu persamaan linier (Trihendradi, 2010:139).

Keterangan :

$$
Y=a+b_{1} X_{1}+b_{2} X_{2}+b_{3} X_{3}
$$

$\mathrm{X}_{1} \quad$ : Variabel $\mathrm{X}_{1}$ jumlah penduduk muslim

$\mathrm{X}_{2} \quad$ : Variabel $\mathrm{X}_{2}$ pembiayaan

$\mathrm{X}_{3}$ : Variabel $\mathrm{X}_{3}$ bagi hasil

a : Konstanta, perpotongan garis pada sumbu $\mathrm{X}_{1}$

$\mathrm{b}_{1} \quad$ : Koefisien regresi untuk $\mathrm{X}_{1}$ jumlah penduduk muslim

$\mathrm{b}_{2} \quad$ : Koefisien regresi untuk $\mathrm{X}_{2}$ pembiayaan

$\mathrm{b}_{3} \quad$ : Koefisien regresi untuk $\mathrm{X}_{3}$ bagi hasil

Y : Variabel Y jumlah nominal tabungan nasabah

\section{METODE PENELITIAN}

Jenis data-data yang digunakan dan sumber data yang akan diolah merupakan serangkaian data yang menjadi pendukung dalam melakukan penelitian. Sumber informasi pada pelaksanaan penelitian diperlukan untuk mendapatkan hasil penelitian yang tepat sesuai realita yang terjadi. Data adalah sekumpulan informasi yang diperlukan untuk pengambilan keputusan (Kuncoro, 2003:124).Data diperoleh dengan mengukur nilai satu atau lebih variabel dalam 
sampel (atau populasi). Data dapat diklafikasikan menjadi dua golongan, yaitu : data kualitatif dan data kuantitatif.

\section{Klasifikasi Variabel dan definisi Operasional}

Klasifikasi variabel terdiri dari dua variabel yaitu variabel terikat dan variabel bebas. Variabel terikat yang menjadi fokus penelitian ini adalah jumlah nominal tabungan nasabah (Y), dan variabel bebas dalam penelitian ini adalah jumlah penduduk muslim $\left(\mathrm{X}_{1}\right)$, pembiayaan $\left(\mathrm{X}_{2}\right)$, dan bagi hasil $\left(\mathrm{X}_{3}\right)$.Variabel terikat (dependent variable). Sedangkan definisi dan pengukuran variabel dalam penelitian ini adalah sebagai berikut :

1. Jumlah penduduk muslim adalah jumlah masyarakat yang beragama islam dan bertempat tinggal menetap di Indonesia.

2. Pembiayaan adalah pembiayaan yang diberikan kepada umat untuk tujuan pembelian barangbarang kebutuhan modal kerja, investasi maupun konsumtif. Dan dalam penelitian ini pengukuran variabel akan digunakan jumlah rupiah pembiayaan yang diberlakukan.

3. Bagi hasil adalah suatu prinsip pembagian keuntungan dan diterapkan dalam kemitraan kerja, dimana porsi bagi hasil ditentukan pada saat akad kerja sama. Variabel ini diukur melalui jumlah rupiah bagi hasil yang dilakukan.

4. Jumlah nominal tabungan nasabah adalah jumlah nominal yang ada pada tabungan nasabah dalam transaksi penyimbanan dana tunai kepada pihak bank.

Lokasi penelitian yang dilakukan melalui website internet dan laporan keuangan tahunan pada Bank Syariah Di Indonesia selama Tahun 2009-2013.

\section{ANALISIS DAN PEMBAHASAN HASIL PENELITIAN}

\section{Hasil Penelitian}

Berdasarkan hasil penelitian yang dilakukan oleh penulis maka diperoleh data-data laporan keuangan tahun 2009, tahun 2010, tahun 2011, tahun 2012 dan tahun 2013 yang bersumber dari PT Bank BRI Syariah, Bank Syariah Bukopin, Bank Syariah Mandiri, Panin Bank Syariah, PT Bank Muamalat Indonesia. Dan masing-masing Bank diambil laporan keuangan selama 5 tahun terakhir sehingga total keseluruhan 25 tahun. Untuk proses pengolahan data laporan keuangan data utama yang diteliti adalah simpanan mudharabah, deposito, pembiayaan, bagi hasil dan jumlah nominal tabungan nasabah yang nilainya telah diuraikan kedalam tabulasi data ordinal.

\section{Uji asumsi klasik}

Untuk menguji keandalan dari persamaan yang akan digunakan dalam menganalisis pengaruh jumlah penduduk muslim $\left(\mathrm{X}_{1}\right)$, pembiayaan $\left(\mathrm{X}_{2}\right)$, dan bagi hasil $\left(\mathrm{X}_{3}\right)$ terhadap jumlah tabungan nasabah (Y) maka dilakukan uji asumsi klasik berupa uji normalitas, uji multikolonearitas dan uji heteroskedastisitas. Uji normalitas bertujuan untuk menguji apakah dalam model regresi, variabel terkait dengan variabel bebas keduanya mempunyai distribusi normal atau tidak. Untuk mengetahui dan berdistribusi secara normal atau tidak yaitu dengan analisis grafik dan uji statistik. Dalam pengujian ini, uji normalitas dideteksi dengan analisis grafik Partial Regression Plot. Uji multikolinearitas digunakan untuk mengetahui apakah terjadi korelasi yang kuat diantara variabel-variabel independen yang diikut sertakan dalam pembentukan model.Hasil coefficients pada out put model, dikatakan tidak terjadi gejala multikolinearitas jika mempunyai nilai tolerance diatas 0.1 atau VIF $<10$. 
Tujuan dari pengujian heteroskedastisitas adalah untuk menguji apakah dalam sebuah model regresi, terjadi ketidaksamaan varians dari residual dari satu pengamatan ke pengamatan yang lain. Jika varians dari residual dari satu pengamatan ke pengamatan yang lain tetap, maka disebut Homoskedastisitas, dan jika varians berbeda disebut Heteroskedastisitas. Model regresi yang baik adalah tidak terjadi Heteroskedastisitas.

\section{Pengujian hipotesis (Uji t)}

Uji parsial (Uji t) dilakukan untuk mengetahui pengaruh variabel independen secara individual (parsial) terhadap variabel dependen. Dengan demikian Ho diterima dan Ha ditolak, hal ini berarti jumlah penduduk muslim $\left(\mathrm{X}_{1}\right)$ tidak berpengaruh signifikan terhadap jumlah nominal tabungan nasabah (Y). Pada kolom signifikansi untuk variabel pembiayaan adalah 0,000 angka ini lebih kecil dari 0,05. Dengan demikian Ho ditolak dan Ha diterima, hal ini berarti pembiayaan $\left(\mathrm{X}_{2}\right)$ berpengaruh terhadap jumlah nominal tabungan nasabah $(\mathrm{Y})$. Pada kolom signifikansi untuk variabel bagi hasil adalah 0,30 angka ini lebih besar dari 0,05. Dengan demikian Ho diterima dan Ha ditolak, hal ini berarti bagi hasil $\left(X_{3}\right)$ tidak berpengaruh signifikan terhadap jumlah nominal tabungan nasabah (Y).

\section{Pembahasan}

\subsection{Jumlah penduduk muslim terhadap jumlah nominal tabungan nasabah}

Hasil pengujian menunjukan bahwa jumlah penduduk muslim tidak berpengaruh signifikan secara statistik terhadap jumlah nominal tabungan nasabah. Dengan demikian hipotesis 1 tidak terdukung karena secara empirik tidak terbukti. Interpretasi dari temuan penelitian ini menunjukan bahwa tidak terdapat hubungan antara jumlah penduduk muslim dan jumlah nominal tabungan nasabah. Hal ini menandakan bahwa jumlah nominal tabungan nasabah tidak didukung oleh jumlah penduduk muslim. Artinya jumlah penduduk muslim tidak mendukung jumlah nominal nasabah.

\subsection{Pembiayaan terhadap jumlah nominal tabungan nasabah}

Hasil pengujian menunjukan bahwapembiayaan berpengaruh signifikan secara statistik terhadap jumlah nominal tabungan nasabah.Dengan demikian hipotesis 2 terdukung karena secara emperik terbukti.Interpretasi dari temuan penelitian ini menunjukan bahwa terdapat hubungan antara pembiayaan dan jumlah nominal tabungan nasabah.Hal ini menandakan bahwa jumlah nominal tabungan nasabah didukung oleh pembiayaan. Artinya pembiayaan mendukung jumlah nominal nasabah.

\subsection{Bagi hasil terhadap jumlah nominal tabungan nasabah}

Hasil pengujian menunjukan bahwa jumlah bagi hasil tidak berpengaruh signifikan secara statistik terhadap jumlah nominal tabungan nasabah. Dengan demikian hipotesis 3 tidak terdukung karena secara empirik tidak terbukti.Interpretasi dari temuan penelitian ini menunjukan bahwa tidak terdapat hubungan antara bagi hasil dan jumlah nominal tabungan nasabah. 


\section{KESIMPULAN DAN SARAN}

1. Jumlah penduduk muslim tidak berpengaruh signifikan terhadap jumlah nominal tabungan nasabah.

2. Pembiayaan berpengaruh signifikan terhadap jumlah nominal tabungan nasabah.

3. Bagi hasil tidak berpengaruh signifikan terhadap jumlah nominal tabungan nasabah.

Saran untuk penelitian selanjutnya disarankan agar dapat memperbanyak sampel lebih dari 25 tahun laporan keuangan dari 5 Bank Syariah di Indonesia atau objek penelitian.

\section{DAFTAR PUSTAKA}

Abimanyu Yoopi, 2004, Memahami Kurs Valuta Asing, Fakultas Ekonomi Universitas Indonesia - Jakarta

Amin A. Riawan, Bunga, Imbalan dan Bagi Hasil, Dalam Majalah Hukum Nasional No.1 Tahun 2000, Jakarta.

Almossawi, 1991, Pengaruh Ketersediaan ATM, Pelayanan Cepat, Respon Petugas Terhadap Keputusan Nasabah Dalam Memilih Bank, Kerja sama antara Bank Indonesia dan Center For Banking Research (CBR) Andalas Univercity

Antonio Muhammad Syafi'i, 2001, Bank Syariah dari Teori Ke Praktek, Gema Insani - Jakarta

Budiono (1998), Bunga adalah "harga" dari (penggunaan) Loanable Funds, landasan teori bunga bank, skripsi.Yogyakarta.

Bank Idonesia (2006), Statistik Perbankan Syariah: Jaringan Kantor Perbankan Syariah 2006, Bank Indonesia, Jakarta.

Bank Indonesia (2006), Perkembangan Perbankan Syariah di Indonesia 2006, Bank Indonesia, Jakarta.

Bank Indonesia. 2003. Bank Indonesia Bank Sentral Republik Indonesia: Tinjauan Kelembagaan, Kebijakan, dan Organisasi. Jakarta: Pusat Pendidikan dan studi.

Danang Sunyoto, 2013,Metodologi Penelitian Akuntansi, PT. Refika Aditama

Duwi Priyatno, 2012, Belajar Praktis Analisis Parametrik Dan Non Parametrik Dengan SPSS

Dan Prediksi Pertanyaan Pendadaran Skripsi Dan Tesis, Gava Media-Yogyakarta

Fadhila Dewi Rahma, 2004, Pengaruh Tingkat Bagi Hasil Dan Suku Bunga Terhadap Simpanan Mudharabah Pada Bank Syariah Mandiri,

http://wordskripsi.blogspot.com/2010/05/bagi-hasil-bank-syariah.html

Fatahullah (2008) Implementasi prinsip bagi hasil dan resiko di Perbankan Syariah.

Ghafur Muhammad W, 2003, Pengaruh Bagi Hasil Suku Bunga Serta Pendapatan Terhadap Simpanan Mudharabah Di Bank Muamalat Indonesia (BMI), http://wordskripsi.blogspot.com/2010/05/bagi-hasil-bank-syariah.html

Haroon dan Ahmad, 2000, Pengaruh Tingkat Bunga Bank Konvensional Terhadap Simpanan Di Bank Syariah, http://www.infoskripsi.com/Proposal/Proposal-Tingkat-Suku-Bunga.html

Halim Alamsyah (2015) Perkembangan dan prospek perbankan syariah di Indonesia.Tantangan dalam menyongsong MEA 2015.

Hendrie Anto. M.B. (2003), Pengantar Ekonomika Islami, Yogyakarta : Ekonisia

Imam Ghozali, 2013, Aplikasi Analisis Multivariatif Dengan Program IBM SPSS 21 Update PLS Regresi, Universitas Diponegoro

Ismail, 2010, Keuangan Dan Investasi Syariah, Sketsa

JusufJopie, 2007, Panduan Dasar Untuk Account Officer, YKPN - Yogyakarta

Kasmir, 2010, Manajemen Perbankan, PT Raja Grafindo Persada - Jakarta 
Kasmir. 2004. Bank dan Lembaga Keuangan Lainnya. Edisi Keenam, PT Raja Grafindo Persada - Jakarta

Kasmir, 2002, Dasar-Dasar Perbankan, PT Raja Grafindo Persada- Jakarta

Khairunnisa, 2000, Faktor-Faktor Yang Mendorong Nasabah Dalam Memilih Bank Syariah, http://downloads.ziddu.com/downloadfile/8931466/Skripsi-Akuntansi-23.zip.html

Kotler, 2002, Manajemen Pemasaran: Perencanaan, implementasi dan pengendalian, Edisi kesembilan, Jilid 1 dan Jilid 2, Penerbit: PT. Prenhallindo, Jakarta.

Kasmir, 2013, Bank Dan Lembaga keuangan Lainnya, PT RajaGrafindo Persada - Jakarta

Lincolin Arsyad, 1999, Pengantar Perencanaan Dan Pembangunan Ekonomi Daerah, Fakultas UGM-Yogyakarta

Miranti Kartika Dewi dan Rahmatina Awaliah Kasri, 2011, Perbankan dan keuangan Islam inovasi pembiayaan UKM, penerapan hawalah dikoperasi islam, Universitas Indonesia

Muhammad, 2005, Bank Syariah, Problem dan prospek perkembangan di Indonesia

Muhammad Afdi Nizar (2007) Analisis pengaruh imbalan hasil dan suku bunga terhadap tabungan (saving deposits) bank syariah dan bank konvensional di Indonesia

Metawa Dan Almossawi, 1998, Pengaruh Perilaku Nasabah Bank Syariah Terhadap Keputusan Memilih Bank Syariah, http://downloads.ziddu.com/downloadfile/8931466/Skripsi-Akuntansi-23.zip.html

Rachbini, D.J. dan Tono, Suwidi. 2000. Bank Indonesia Menuju Independensi Bank Sentral. Jakarta: PT Mardi Mulya.

Simorangkir, 2004, Pengantar Lembaga Keuangan Bank dan Non Bank, Ghalia IndonesiaJakarta

Sihombing Jonker, 2010, Penjamin Simpanan Nasabah Perbankan, PT Alumni - Bandung

Singgih Santoso, 2012, Panduan Lengkap SPSS Versi 20, PT elex Komputindo-Jakarta

Sony Warsono Bin Hardono, 2011, Akuntansi Transaksi Syari'ah, Asgard Chapter - Yogyakarta

Sri Nurhayati, 2009, Akuntansi Syariah Di Indonesia, Salemba Empat - Jakarta

Sugiono, 2011, Metode Penelitian Kuantitatif Kualitatif dan R \& D, Alfabeta - Bandung

Suharsimi Arikunto, 2002. Prosedur Penelitian: Suatu Pendekatan Praktek. Jakarta: PT Rineka Cipta.

Standar Akuntansi Keuangan, per 1 Juli 2009, Salemba Empat, Jakarta

Sutiani, 2012, Hubungan Imbalan bagi hasil, pembiayaan, dan suku bunga terhadap jumlah nominal tabungan Nasabah Pada Bank Syariah Indonesia, Program Magister Akuntansi, Fakultas Ekonomi Universitas Sam Ratulangi-Manado

Trihendradi, 2010, Step by Step SPSS 18 Analisis Data Statistik, Andi-Yogyakarta

Ulfatuz Zaqiyyah (2011-2013) Pengaruh besar kecilnya dana pihak ketiga mudharabah terhadap pembiayaan mudharabah di BPRS Amanah Sejahtera Gresik

Veni Rahmi Yusni (2011), Analisis faktor-faktor yang mempengaruhi peningkatan jumlah tabungan masyarakat pada BPR Syariah Puduarta Insani.

Widarjono Agus, (2005), "Ekonometrika Teori dan Aplikasi", Ekonisia, Yogyakarta.

Widiastama Siffa, 2006, Pengaruh Total Bagi Hasil Tingkat Suku Bunga Deposito Dan Fatwa MUI Yang Terkait Dengan Haramnya Bunga Bank Terhadap Simpanan Mudharabah Pada Bank Muamalat Indonesia,

Jaharudiin, 2004, Faktor-faktor yang mempengaruhi perkembangan perbankan syariah di Indonesia. 